\title{
Marketing Techniques and Clients’ Engagement in Rural Bank of Paete, Inc.
}

\author{
Valdecantos, April D. \\ ${ }^{\mathrm{a}}$ kirstencluster2@gmail.com \\ ${ }^{a}$ Laguna College of Business and Arts (LCBA), Calamba City, Philippines
}

\begin{abstract}
The purpose of this study was to determine which marketing techniques influenced the consumer's decision to stay with or leave Rural Bank of Paete, Inc. Marketing involves meeting the needs and desires of customers. As a result, any company's objective is to provide value to customers while making a profit. The descriptive-correlational research methodologies were used in this study. The study's respondents were 210 clients and 20 staff of the Rural Bank of Paete, Inc., who were chosen by purposive sampling. Data was collected using validated adapted survey questionnaires. This resulted in a .985 after pilot testing. The findings demonstrated that the marketing techniques for client acquisition, service quality, and price perception were all highly observed using a four-point Likert Scale and the simple mean, t-test for independent samples, and Pearson-r correlation coefficient. In terms of marketing technique and client engagement, there were no major differences in the opinions of the two groups of respondents. Clients' engagement in terms of customer satisfaction, value offers, and loyalty was also observed. To keep clients engaged, the company should continue to improve its marketing strategies. Furthermore, the output of the study is a marketing design to help improve the current status and further sustain the clients' engagement with Rural Bank of Paete, Inc.
\end{abstract}

Keywords: Marketing techniques; Clients' engagement

\section{Introduction}

Marketing involves satisfying clients' needs and wants. Thus, the mission of any business is to deliver customer value at a corresponding profit. Most banks offer the same products and services, but can only differentiate themselves by price and quality. The 7Ps of marketing with which this study is anchored cover the important layers of retaining business clients. This set of marketing mix has been adopted by service industries since the application of the basic marketing mix, more popularly known as 4Ps, is not enough to promote customer satisfaction thereby leading to possible client retention. As cited by R. Ravangard, A. Khodadad, \& P. Bastani (2020) in their published work in jepha.springeropen.com, marketing is an important part of any business operation which composes the process of planning, promotion, pricing, and delivery of customer-oriented products or services. It is considered as a mix of necessary components required for a more comprehensive design and seamless execution of the business marketing mix. This marketing mix is a very crucial tool empowering executives and managers to stay competitive in the global business environment.

The overall mission and objectives are defined in the company's strategic plan. The role of marketing is to summarize the significant activities involved to implement a customer-driven marketing plan and marketing mix. To create value for the organization and to establish a profitable customer relationship, the focus of marketing must be on the clients or customers. Another factor is the marketing strategy that deals with the marketing tactic which enables the company to create value and achieve a profitable customer relationship (Principles of Marketing 17 ${ }^{\text {th }}$ Edition, Kotler and Armstrong, 2017). 
Furthermore, Fertik (2019) mentioned that it is important to have a customer base that is willing to take part in the business and experience the value that has been created for them. It is about inspiring the customers to engage in your business, making them loyal, and driving revenue in return.

The proponent of this study assessed the level of practice of marketing techniques and the level of observance of clients' engagement to establish a marketing design that may help to improve the current status of Rural Bank of Paete, Inc.

\section{Theoretical/Conceptual Framework}

This study was anchored on the 7Ps model of marketing as developed by Booms and Bitner. Booms, B. \& Bitner, M.J. (1981) Marketing Management, 15 ${ }^{\text {th }}$ Edition by Philip Kotler and Kevin Lane Keller (2017) in their study on Marketing. Consequently, the marketing mix is defined as the set of tactical marketing tools that a business blends to produce the response it wants in the target market.

The researcher utilized the independent and dependent variables to identified and determined the level of efficiency of marketing strategy and the level of the clients' engagement in Rural Bank of Paete, Inc. as a basis for coming up with a paradigm as shown in illustrations:

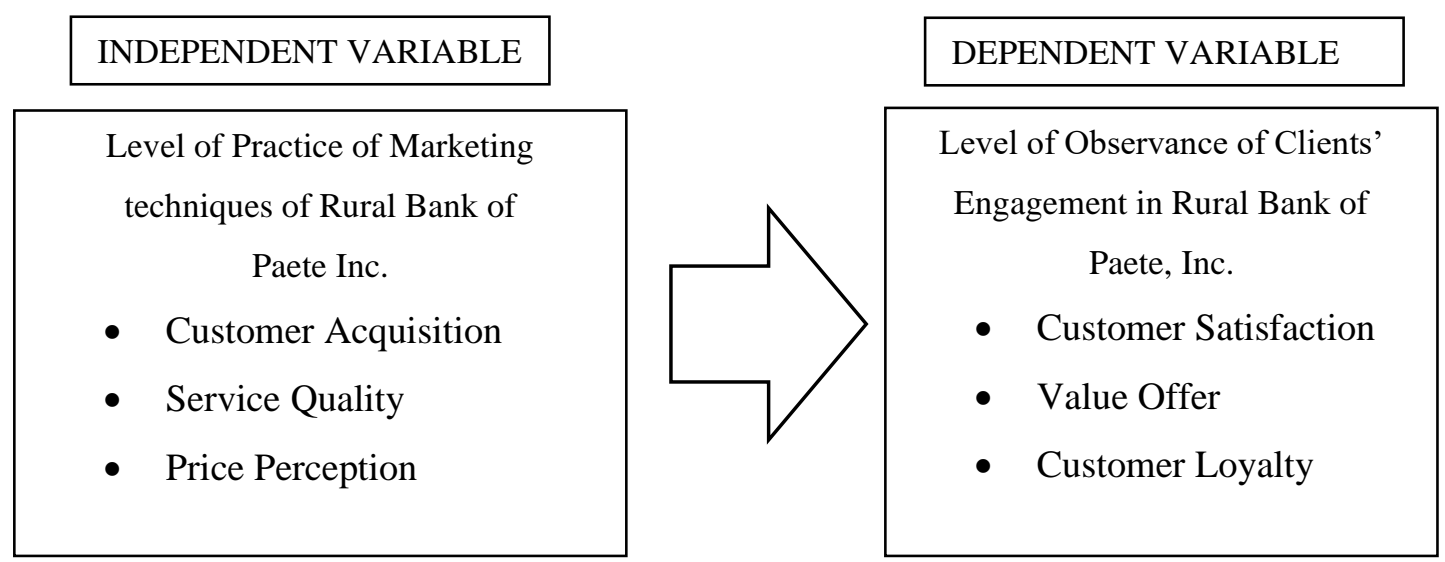

Figure 1. Research Paradigm

The independent variables are the marketing strategy in terms of customer acquisition, service quality, and price perception. The dependent variables are the clients' engagement in terms of customer satisfaction, value offer, and customer loyalty. The process of the study involved problem identification, data analysis, and correlation analysis that developed marketing and sustained the client's engagement plan.

\section{Hypotheses}

The hypotheses that follow were tested at 0.05 level of significance:

a. There is no significant difference between the responses of the two groups of respondents on the marketing techniques and clients' engagement in Rural Bank of Paete, Inc.

b. There is a significant relationship between the marketing techniques and clients' engagement in Rural Bank of Paete, Inc. 


\section{Scope and Delimitation}

The researcher was limited to the assessment of the marketing techniques and clients' engagement practices in Rural Bank of Paete, Inc. The respondents of the study consisted of the present officers and staff and its selected client. The data will be gathered through questionnaires and accompanied by observations and interviews.

\section{Methodology}

The descriptive-correlational research design was used for this study. The study aimed to describe the influence of marketing techniques on clients' engagement because the researcher believes that there is a sense of dependency between each other. A descriptive study had also tried to generalize the findings from a representative sample to a larger target population as in a cross-sectional survey. The methods of collecting data for descriptive research had been employed singly or in various combinations, depending on the research questions at hand. Some of the common data collection methods applied to questions within the realm of descriptive research include survey questionnaires, interviews, checklists, and sampling. The instrumentation used to collect data for this thesis was a survey questionnaire. The survey questionnaire was also calculated using Cronbach's Alpha resulting in .985 and has been into Pilot Testing. To limit the sample size, the GPower Calculator was used. The respondents of the study were the employees and clients of Rural Bank of Paete, Inc. These were the individuals who participated in this research. Through purposive sampling, the respondents of the study were two hundred ten (210) clients and twenty (20) employees from the Rural Bank of Paete, Inc. Validated modified survey questionnaires were used for gathering data. After gathering all the complete questionnaires from the respondents, total responses for each item will be presented.

1. Mean and the four-point Likert Scale was used to determine the level of practice of marketing techniques and the level of clients' engagement in Rural Bank of Paete, Inc.

2. T-test was used to determine the significant difference between the assessment of the two groups of respondents on marketing techniques and clients' engagement in Rural Bank of Paete, Inc.

3. To establish the relationship between the level of practice of marketing techniques and clients' engagement in Rural Bank of Paete, Inc., Pearson Correlation Coefficient (Pearson's r) was used.

\section{Results and Discussion}

Table 1.1

Level of Practice of Marketing Techniques in Rural Bank of Paete, Inc. as Assessed by Employees and Clients in terms of Customer Acquisition

\begin{tabular}{|c|c|c|c|c|c|c|}
\hline \multirow{2}{*}{ Indicators in terms of Customer Acquisition } & \multicolumn{2}{|c|}{ Employees } & \multicolumn{2}{|c|}{ Clients } & \multicolumn{2}{|c|}{ Composite } \\
\hline & $\bar{x}$ & VI & $\bar{x}$ & VI & $\bar{x}$ & VI \\
\hline $\begin{array}{l}\text { 1. The company has a thorough understanding of the } \\
\text { bank marketplace. }\end{array}$ & 3.70 & $\mathrm{HO}$ & 3.66 & $\mathrm{HO}$ & 3.68 & $\mathrm{HO}$ \\
\hline 2. The company has a mechanism for identifying clients. & 3.70 & $\mathrm{HO}$ & 3.59 & $\mathrm{HO}$ & 3.65 & $\mathrm{HO}$ \\
\hline $\begin{array}{l}\text { 3. The company is utilizing multiple channels to increase } \\
\text { its chances of finding quality leads (clients.) }\end{array}$ & 3.40 & $\mathrm{HO}$ & 3.59 & $\mathrm{HO}$ & 3.49 & $\mathrm{HO}$ \\
\hline $\begin{array}{l}\text { 4. The company's advertising campaigns show the } \\
\text { relevance of bank services/ products to customer needs. }\end{array}$ & 3.35 & $\mathrm{HO}$ & 3.58 & $\mathrm{HO}$ & 3.46 & $\mathrm{HO}$ \\
\hline $\begin{array}{l}\text { 5. Existing clients influence their friends and relatives to } \\
\text { avail of the bank's products. }\end{array}$ & 3.55 & $\mathrm{HO}$ & 3.57 & $\mathrm{HO}$ & 3.56 & $\mathrm{HO}$ \\
\hline GENERAL ASSESSMENT & 3.54 & $\mathrm{HO}$ & 3.60 & $\mathrm{HO}$ & 3.57 & $\mathrm{HO}$ \\
\hline $\begin{array}{ll}\text { Legend: } & 3.25-4.00 \text { Highly Observed }(\mathrm{HO}) \\
& 2.50-3.24 \text { Observed }(\mathrm{O})\end{array}$ & & Sliq & ved & & & \\
\hline
\end{tabular}


Table 1.1 shown that the level of practice of the marketing techniques in terms of customer acquisition has an aggregate general assessment of 3.57. The Company has a thorough understanding of the bank marketplace has a composite mean of 3.68. The Company's advertising campaigns show the relevance of bank services/ products to customer needs has a mean of 3.46.

All these variables are interpreted as Highly Observed. It is an effort and part of the job of any business to work on attracting new customers. However, the fact of customer migration is a common phenomenon happening in the actual competitive environment. Therefore, lost customers must be replaced, and this process involves specific activities of identifying prospective clients, selecting the communication channel, and having adequate resources for targeting new and potential customers.

Table 1.2

Level of Practice of Marketing Techniques in Rural Bank of Paete, Inc. as Assessed by Employees and Clients in terms of Service Quality

\begin{tabular}{|c|c|c|c|c|c|c|}
\hline \multirow{2}{*}{ Indicators in terms of Service Quality } & \multicolumn{2}{|c|}{ Employees } & \multicolumn{2}{|c|}{ Clients } & \multicolumn{2}{|c|}{ Composite } \\
\hline & $\bar{x}$ & VI & $\bar{x}$ & VI & $\bar{x}$ & VI \\
\hline 1. Bank is consistent in providing good quality service. & 3.75 & $\mathrm{HO}$ & 3.74 & $\mathrm{HO}$ & 3.74 & $\mathrm{HO}$ \\
\hline $\begin{array}{l}\text { 2. Bank offers personalized services to meet customer's } \\
\text { needs. }\end{array}$ & 3.65 & $\mathrm{HO}$ & 3.69 & $\mathrm{HO}$ & 3.67 & $\mathrm{HO}$ \\
\hline $\begin{array}{l}\text { 3. The frontline employees of this bank are always willing } \\
\text { to help me. }\end{array}$ & 3.45 & $\mathrm{HO}$ & 3.67 & $\mathrm{HO}$ & 3.56 & HO \\
\hline $\begin{array}{l}\text { 4. Response to consumers' complaints is always taken } \\
\text { care of. }\end{array}$ & 3.65 & $\mathrm{HO}$ & 3.70 & $\mathrm{HO}$ & 3.67 & $\mathrm{HO}$ \\
\hline $\begin{array}{l}\text { 5. The employees follow up on customer requests in a } \\
\text { timely manner. }\end{array}$ & 3.60 & $\mathrm{HO}$ & 3.67 & $\mathrm{HO}$ & 3.63 & $\mathrm{HO}$ \\
\hline GENERAL ASSESSMENT & 3.62 & $\mathrm{HO}$ & 3.69 & $\mathrm{HO}$ & 3.66 & $\mathrm{HO}$ \\
\hline
\end{tabular}

As shown in Table 1.2, the level of practice of the marketing techniques in terms of service quality has an aggregate general assessment of 3.66. The bank is consistent in providing good quality service has a composite mean of 3.74. The frontline employees of this bank are always willing to help clients has a mean of 3.56. All these variables are interpreted by clients and employees as Highly Observed.

In such a sense, good service quality is a competitive advantage to attract and retain customers and make a profit.

Table 1.3

Level of Practice of Marketing Techniques in Rural Bank of Paete, Inc. as Assessed by Employees and Clients in terms of Price Perception

\begin{tabular}{|c|c|c|c|c|c|c|}
\hline \multirow{2}{*}{ Indicators in terms of Price Perception } & \multicolumn{2}{|l|}{ Employees } & \multicolumn{2}{|c|}{ Clients } & \multicolumn{2}{|c|}{ Composite } \\
\hline & $\bar{x}$ & VI & $\bar{x}$ & VI & $\bar{x}$ & VI \\
\hline $\begin{array}{l}\text { 1. Bank utilizes effective ways to help employees know } \\
\text { its pricing policies of products and services. }\end{array}$ & 3.35 & $\mathrm{HO}$ & 3.62 & $\mathrm{HO}$ & 3.49 & $\mathrm{HO}$ \\
\hline 2. The interest rate offered by this bank is reasonable. & 3.45 & $\mathrm{HO}$ & 3.47 & $\mathrm{HO}$ & 3.46 & $\mathrm{HO}$ \\
\hline $\begin{array}{l}\text { 3. Bank offers a flexible interest rate for various services } \\
\text { that meet my needs. }\end{array}$ & 3.55 & $\mathrm{HO}$ & 3.50 & $\mathrm{HO}$ & 3.52 & $\mathrm{HO}$ \\
\hline $\begin{array}{l}\text { 4. Interest rates of products and services from this bank } \\
\text { are attractive. }\end{array}$ & 3.40 & $\mathrm{HO}$ & 3.50 & $\mathrm{HO}$ & 3.45 & HO \\
\hline 5. Value for money is highly observed. & 3.60 & $\mathrm{HO}$ & 3.50 & $\mathrm{HO}$ & 3.55 & $\mathrm{HO}$ \\
\hline GENERAL ASSESSMENT & 3.47 & $\mathrm{HO}$ & 3.52 & $\mathrm{HO}$ & 3.49 & $\mathrm{HO}$ \\
\hline $\begin{array}{ll}\text { egend: } & 3.25-4.00 \text { Highly Observed }(\mathrm{HO}) \\
& 2.50-3.24 \text { Observed }(\mathrm{O})\end{array}$ & $\begin{array}{l}1.75- \\
1.00-\end{array}$ & $\begin{array}{l}9 \text { Sligh } \\
4 \text { Not }\end{array}$ & $\begin{array}{l}\text { Observe } \\
\text { rved (N }\end{array}$ & & & \\
\hline
\end{tabular}


The level of practice of the marketing techniques in terms of price perception has an aggregate general assessment of 3.49. The value for money is highly observed has a composite mean of 3.55. Meanwhile, interest rates of products and services from this bank are attractive has a mean of 3.45. All these variables are interpreted by clients and employees as Highly Observed.

The above-mentioned findings of the study imply that there is a Highly Observed level of practice of marketing techniques in Rural Bank of Paete, Inc. is more likely to be affected by the price.

Table 2.1

Level of Observance of Clients' Engagement in Rural Bank of Paete, Inc. as Assessed by the Employees and Clients in terms of Customer Satisfaction

\begin{tabular}{|c|c|c|c|c|c|c|}
\hline \multirow{2}{*}{ Indicators in terms of Customer Satisfaction } & \multicolumn{2}{|c|}{ Employees } & \multicolumn{2}{|c|}{ Clients } & \multirow{2}{*}{$\begin{array}{c}\text { Composite } \\
\overline{\boldsymbol{x}}\end{array}$} & \multirow[b]{2}{*}{$\mathrm{I}$} \\
\hline & $\bar{x}$ & VI & $\bar{x}$ & VI & & \\
\hline $\begin{array}{l}\text { 1. I am satisfied with the overall service quality offered by } \\
\text { this bank. }\end{array}$ & 3.55 & $\mathrm{HO}$ & 3.71 & $\mathrm{HO}$ & 3.63 & $\mathrm{HO}$ \\
\hline $\begin{array}{l}\text { 2. I am satisfied with the professional competence of this } \\
\text { bank. }\end{array}$ & 3.55 & $\mathrm{HO}$ & 3.67 & $\mathrm{HO}$ & 3.61 & $\mathrm{HO}$ \\
\hline $\begin{array}{l}\text { 3. I am satisfied with the performance of the frontline } \\
\text { employees of this bank. }\end{array}$ & 3.60 & $\mathrm{HO}$ & 3.67 & $\mathrm{HO}$ & 3.63 & $\mathrm{HO}$ \\
\hline $\begin{array}{l}\text { 4. I am comfortable with the business relationship with } \\
\text { this bank. }\end{array}$ & 3.65 & $\mathrm{HO}$ & 3.68 & $\mathrm{HO}$ & 3.66 & $\mathrm{HO}$ \\
\hline 5. The policies and practices of this bank are trustworthy. & 3.85 & $\mathrm{HO}$ & 3.70 & $\mathrm{HO}$ & 3.77 & $\mathrm{HO}$ \\
\hline GENERAL ASSESSMENT & 3.64 & $\mathrm{HO}$ & 3.68 & $\mathrm{HO}$ & 3.66 & $\mathrm{HO}$ \\
\hline $\begin{array}{ll}\text { Legend: } & 3.25-4.00 \text { Highly Observed }(\mathrm{HO}) \\
& 2.50-3.24 \text { Observed }(\mathrm{O})\end{array}$ & $\begin{array}{l}1.75 \\
1.00\end{array}$ & & ( $(\mathrm{NO})$ & & & \\
\hline
\end{tabular}

Table 2.1 shown that the level of observance in clients' engagement in terms of customer satisfaction has an aggregate general assessment of 3.66. The indicator "I am satisfied with the overall service quality offered by this bank." has the highest composite mean of $\mathbf{3 . 7 7}$ while the indicator "I am satisfied with the professional competence of this bank" has the least computed composite mean of 3.61. In addition, both the employees and customers assessed Customer Satisfaction as Highly Observed.

The result implies that the level of observance of clients' engagement is evident that the customers are happy with the company's products and services. It means that their need is met effortlessly in a convenient way that makes them satisfied. Customer satisfaction is essential to keep your current customers and retaining new ones.

Table 2.2

Level of Observance of Clients' Engagement in Rural Bank of Paete, Inc. as Assessed by Employees and Clients in terms of Value Offers

\begin{tabular}{|c|c|c|c|c|c|c|}
\hline \multirow{2}{*}{ Indicators in terms of Value Offers } & \multicolumn{2}{|c|}{ Employees } & \multicolumn{2}{|c|}{ Clients } & \multicolumn{2}{|c|}{ Composite } \\
\hline & $\bar{x}$ & VI & $\bar{x}$ & VI & $\overline{\boldsymbol{x}}$ & VI \\
\hline $\begin{array}{l}\text { 1. Bank gives rewards such as rebates and other } \\
\text { promotional offers. }\end{array}$ & 3.65 & $\mathrm{HO}$ & 3.56 & $\mathrm{HO}$ & 3.60 & $\mathrm{HO}$ \\
\hline $\begin{array}{l}\text { 2. The promotional offers from this bank were worth the } \\
\text { money. }\end{array}$ & 3.25 & $\mathrm{HO}$ & 3.45 & $\mathrm{HO}$ & 3.35 & $\mathrm{HO}$ \\
\hline $\begin{array}{l}\text { 3. It was hassle-free to get benefits from the promotional } \\
\text { offers. }\end{array}$ & 3.40 & $\mathrm{HO}$ & 3.50 & $\mathrm{HO}$ & 3.45 & $\mathrm{HO}$ \\
\hline 4. It is likely that I will achieve the proposed reward. & 3.40 & $\mathrm{HO}$ & 3.55 & $\mathrm{HO}$ & 3.48 & $\mathrm{HO}$ \\
\hline $\begin{array}{l}\text { 5. Bank provides solutions that are actually valuable to } \\
\text { the client. }\end{array}$ & 3.55 & $\mathrm{HO}$ & 3.58 & $\mathrm{HO}$ & 3.56 & $\mathrm{HO}$ \\
\hline GENERAL ASSESSMENT & 3.45 & $\mathrm{HO}$ & 3.53 & $\mathrm{HO}$ & 3.49 & $\mathrm{HO}$ \\
\hline $\begin{array}{ll}\text { Legend: } & 3.25-4.00 \text { Highly Observed }(\mathrm{HO}) \\
& 2.50-3.24 \text { Observed }(\mathrm{O})\end{array}$ & & & N & & & \\
\hline
\end{tabular}


As shown in Table 2.2, the level of observance of clients' engagement in terms of value offer has an aggregate general assessment of 3.49. The bank gives rewards such as rebates and other promotional offers that have a composite mean of 3.60. The promotional offers from this bank were worth the money has a mean of 3.35. All these variables are interpreted as Highly Observed.

This implies that the company has an established and healthy relationship with its clients in terms of value offers. However, the company may still need to provide high-value products and services and establish a more modest and reasonable improvement with their clients, it is suggested to further identify new sources of competitive advantage and new ways to improve customer service strategies and experience management.

Table 2.3

Level of Observance of Clients' Engagement in Rural Bank of Paete, Inc. as Assessed by Employees and Clients in terms of Customer Loyalty

\begin{tabular}{|c|c|c|c|c|c|c|}
\hline \multirow{2}{*}{ Indicators in terms of Customer Loyalty } & \multicolumn{2}{|c|}{ Employees } & \multicolumn{2}{|c|}{ Clients } & \multicolumn{2}{|c|}{ Composite } \\
\hline & $\bar{x}$ & VI & $\bar{x}$ & VI & $\bar{x}$ & VI \\
\hline $\begin{array}{l}\text { 1. I intend to continue doing financial services from this } \\
\text { bank for a long time. }\end{array}$ & 3.65 & $\mathrm{HO}$ & 3.70 & $\mathrm{HO}$ & 3.68 & $\mathrm{HO}$ \\
\hline $\begin{array}{l}\text { 2. I am willing to say positive things about this bank to } \\
\text { other people. }\end{array}$ & 3.65 & $\mathrm{HO}$ & 3.61 & $\mathrm{HO}$ & 3.63 & $\mathrm{HO}$ \\
\hline $\begin{array}{l}\text { 3. I will encourage friends and relatives to avail financial } \\
\text { services offered by this bank. }\end{array}$ & 3.60 & $\mathrm{HO}$ & 3.63 & $\mathrm{HO}$ & 3.62 & $\mathrm{HO}$ \\
\hline 4. I am not thinking of switching to another bank(s). & 3.55 & $\mathrm{HO}$ & 3.58 & $\mathrm{HO}$ & 3.56 & $\mathrm{HO}$ \\
\hline 5. For me, this bank is able to provide the best service. & 3.60 & $\mathrm{HO}$ & 3.59 & $\mathrm{HO}$ & 3.60 & $\mathrm{HO}$ \\
\hline GENERAL ASSESSMENT & 3.61 & $\mathrm{HO}$ & 3.62 & $\mathrm{HO}$ & 3.62 & $\mathrm{HO}$ \\
\hline $\begin{array}{ll}\text { Legend: } & 3.25-4.00 \text { Highly Observed }(\mathrm{HO}) \\
& 2.50-3.24 \text { Observed }(\mathrm{O})\end{array}$ & $+\mathrm{N}$ & ( & & & & \\
\hline
\end{tabular}

Table 2.3 shows that the level of observance of the clients' engagement in Rural Bank of Paete, Inc. as assessed by the employees and clients in terms of Customer Loyalty. The general assessment was 3.62 which was verbally interpreted as "Highly Observed". The indicator "I intend to continue doing financial services from this bank for a long time" has the highest composite mean of $\mathbf{3 . 6 8}$ while the indicator "I am not thinking of switching to another bank(s)" has the least computed composite mean of 3.56. Creating a value of a relationship with the customer has resulted in developing customers' trust and loyalty. Customers need to be prioritized, and service employees' have to help customers who need assistance consistently. 
Table 3.1

Test of Significant Difference on the Assessment of Employees and Clients on Marketing Techniques in Rural Bank of Paete, Inc. in terms of Customer Acquisition, Service Quality, and Price Perception

\begin{tabular}{|c|c|c|c|c|c|c|c|}
\hline & Sum of squares & Df & $\begin{array}{l}\text { Mean } \\
\text { square }\end{array}$ & F Ratio & Sig. & Remarks & Decision \\
\hline $\begin{array}{l}\text { Customer Acquisition } \\
\text { Between Groups }\end{array}$ & .060 & 1 & .060 & .331 & .566 & Not Significant & Accept $\mathrm{H}_{o}$ \\
\hline Within Groups & 37.447 & 205 & .183 & & & & \\
\hline Total & 37.508 & 206 & & & & & \\
\hline $\begin{array}{l}\text { Service Quality } \\
\text { Between Groups }\end{array}$ & .096 & 1 & .096 & .641 & .641 & Not Significant & Accept $\mathrm{H}_{o}$ \\
\hline Within Groups & 30.813 & 205 & .150 & & & & \\
\hline Total & 30.909 & 206 & & & & & \\
\hline $\begin{array}{l}\text { Price Perception } \\
\text { Between Groups }\end{array}$ & .043 & 1 & .043 & .233 & .630 & Not Significant & Accept $\mathrm{H}_{o}$ \\
\hline Within Groups & 37.666 & 205 & .184 & & & & \\
\hline Total & 37.709 & 206 & & & & & \\
\hline
\end{tabular}

As shown in Table 3.1, the test of significant difference in the assessment of employees and clients on marketing techniques. The respondents have similar perceptions in all the cited variables. As shown in their probability values of $.566, .641$, and .630 which were greater than the level of significance of 0.05 . Thus, the null hypothesis is accepted. It goes to show that there is no significant difference between the responses of the two groups of respondents on the marketing techniques. This simply means that the responses of internal and external stakeholders are parallel in terms of Customer Acquisition, Service Quality, and Price Perception in terms of marketing techniques. Quality of service and price perception play a vital role in acquiring new clients.

Moreover, as shown in Table 3.2 the generated computed probability values of Customer Satisfaction, Value Offers, and Customer Loyalty were .649,.437, and .894 which were greater than the level of significance of 0.05 ; thus, the null hypothesis is accepted. Therefore, there is no significant difference between the responses of the two groups of respondents on clients' engagement. It implies that the responses of internal and external stakeholders are parallel in terms of Customer Satisfaction, Value Offers, and Customer Loyalty when it comes to clients' engagement.

Table 3.2

Test of Significant Difference on the Assessment of Employees and Clients on Clients' Engagement in Rural Bank of Paete, Inc. in terms of Customer Satisfaction, Value Offers, and Customer Loyalty

\begin{tabular}{|c|c|c|c|c|c|c|c|}
\hline & Sum of squares & Df & Mean square & F Ratio & Sig. & Remarks & Decision \\
\hline $\begin{array}{l}\text { Customer Satisfaction } \\
\text { Between Groups }\end{array}$ & .034 & 1 & .034 & .208 & .649 & Not Significant & Accept $\mathrm{H}_{\mathrm{o}}$ \\
\hline Within Groups & 33.627 & 205 & .164 & & & & \\
\hline Total & 33.661 & 206 & & & & & \\
\hline $\begin{array}{l}\text { Value Offers } \\
\text { Between Groups }\end{array}$ & .108 & 1 & .108 & .606 & .437 & Not Significant & Accept $\mathrm{H}_{\mathrm{o}}$ \\
\hline Within Groups & 36.521 & 205 & .178 & & & & \\
\hline Total & 36.629 & 206 & & & & & \\
\hline $\begin{array}{l}\text { Customer Loyalty } \\
\text { Between Groups }\end{array}$ & .003 & 1 & .003 & .018 & .894 & Not Significant & Accept $\mathrm{H}_{\mathrm{o}}$ \\
\hline Within Groups & 37.934 & 205 & .185 & & & & \\
\hline Total & 37.938 & 206 & & & & & \\
\hline
\end{tabular}


Table 4

Significant Relationship between the Level of Practices of Marketing Techniques and Observance of Clients' Engagement in Rural Bank of Paete, Inc.

\begin{tabular}{cccccc}
\hline \multirow{2}{*}{ Marketing Techniques } & Clients' Engagement & r value & P value & Remarks & Decision \\
& Customer Satisfaction & $.613^{* *}$ & .000 & Significant & Reject $\mathrm{H}_{\mathrm{o}}$ \\
\multirow{3}{*}{ Customer Acquisition } & Value Offers & $.696^{* *}$ & .000 & Significant & Reject $\mathrm{H}_{\mathrm{o}}$ \\
& Customer Loyalty & $.623^{* *}$ & .000 & Significant & Reject $\mathrm{H}_{\mathrm{o}}$ \\
\hline \multirow{3}{*}{ Service Quality } & Customer Satisfaction & $.759^{* *}$ & .000 & Significant & Reject $\mathrm{H}_{\mathrm{o}}$ \\
& Value Offers & $.542^{* *}$ & .000 & Significant & Reject $\mathrm{H}_{\mathrm{o}}$ \\
& Customer Loyalty & $.666^{* *}$ & .000 & Significant & Reject $\mathrm{H}_{\mathrm{o}}$ \\
\hline \multirow{2}{*}{ Price Perception } & Customer Satisfaction & $.622^{* *}$ & .000 & Significant & Reject $\mathrm{H}_{\mathrm{o}}$ \\
& Value Offers & $.638^{* *}$ & .000 & Significant & Reject $\mathrm{H}_{\mathrm{o}}$ \\
& Customer Loyalty & $.584^{* *}$ & .000 & Significant & Reject $\mathrm{H}_{\mathrm{o}}$ \\
\hline
\end{tabular}

***Correlational at the level 0.01

*Correlational at the level 0.05(Two-tailed)

Table 4 identified that there was a significant relationship between the level of practice of marketing techniques and clients' engagement in Rural Bank of Paete, Inc. The $r$ values of all variables were interpreted as moderate to high positive correlation and the computed probability values were less than the level of significant $(\mathrm{P}<0.05)$; thus, the null hypothesis is rejected. It has been concluded that there is a significant relationship between the level of observance of the dependent and independent variables. Successful customer engagement will keep your products and services at the top of the customer's mind when it comes to the decision-making process. It will also make the clients more responsive to your marketing efforts and tend to become repeat customers, and repeat customers are vital to business success.

As an output, a marketing design is proposed for the bank in sustaining clients' engagement which is simple, straightforward, and easy to understand. Marketing techniques are essentials that every bank must provide. Nowadays, with the rise of social media, Rural Bank of Paete, Inc. may also consider having a virtual suggestion box for both employees and clients. With the use of IdeaScale, you can implement a suggestion box within minutes and start collecting suggestions from your customer and employee in an instant to improve and optimize a business for success.

Table 5 below shows the marketing designed matrix in clients' engagement for Rural Bank of Paete, Inc. 
Table 5

Proposed Marketing Design for Rural Bank of Paete, Inc.

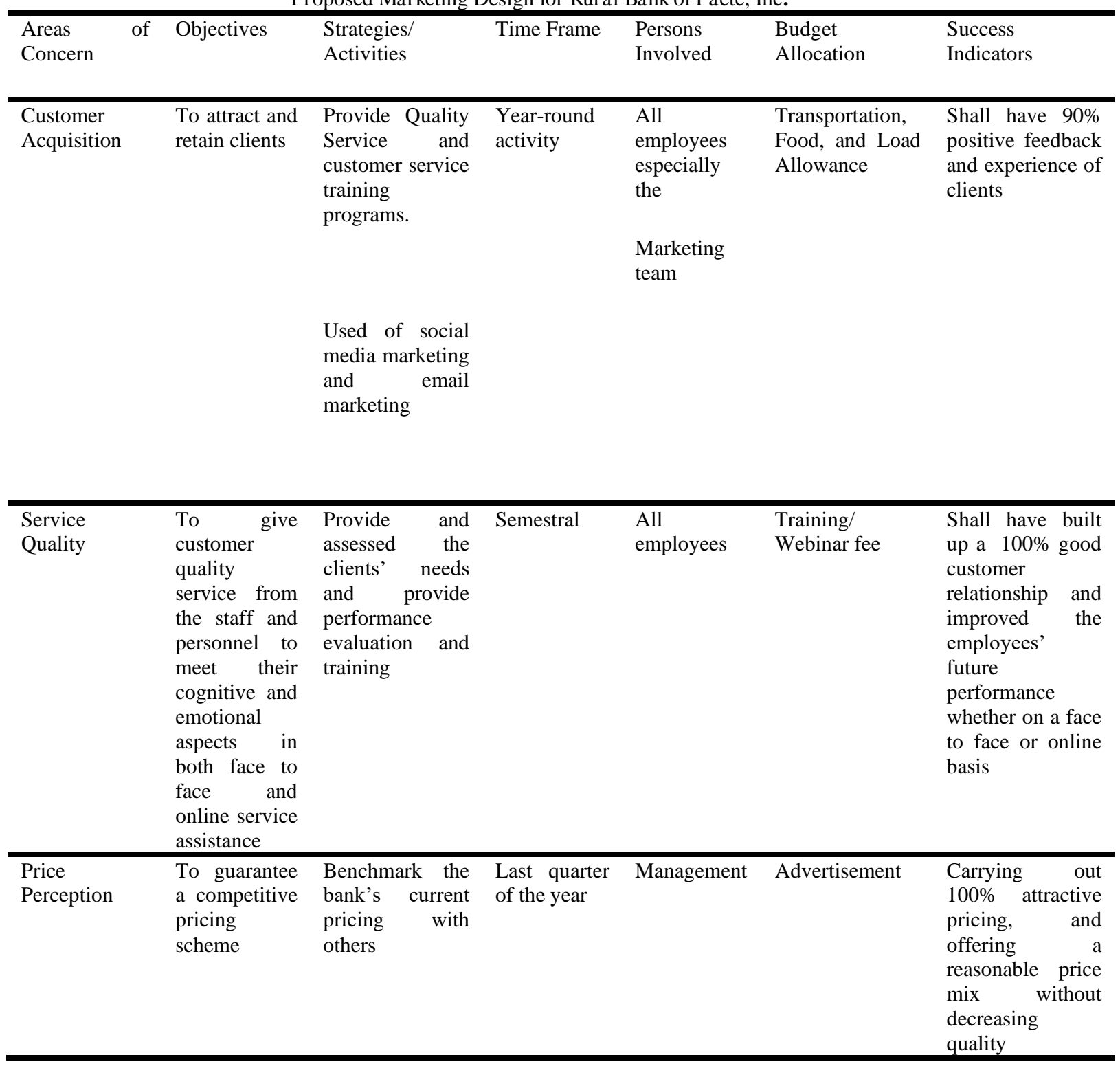

\section{Recommendation}

Based on the aforementioned results of the study, the following conclusions have been generated:

1.1 The company has a thorough understanding of the bank marketplace to acquire new customers is Highly Observed while the company's advertising campaigns show the relevance of bank services/ products to customer needs although Highly Observed points out that the clients considered bank 
marketplace as a long-term decision as it is the most significant factor in clients' engagement in Rural Bank of Paete, Inc.

1.2 That the bank's consistency in providing good quality service is Highly Observed while the frontline employees of the bank are always willing to help clients did not obtain the same general assessment as the previous is still believe to be Highly Observed.

1.3 That in terms of value for money is highly observed and the interest rate of products and services from this bank are attractive were both considered as Highly Observed even though the latter obtained the lowest mean as assessed by the respondents.

2.1 When it comes to customer satisfaction respondents are Highly Observed for both being satisfied with the overall service quality offered by this bank and being satisfied with the professional competence of this bank.

2.2 As the bank gives rewards such as rebates and other promotional offers are Highly Observed and while the promotional offers from this bank were worth the money did not acquire the same general assessment as the aforementioned is still believed to be Highly Observed.

2.3 That in terms of Customer Loyalty specifics is highly observed and the bank has established customer-centered approaches that recognize the want and interest of the service receiver.

3. The respondents have the same perception as to the marketing techniques and clients' engagement in Rural Bank of Paete, Inc.

4. That there is a significant relationship between the level of practice of the respondents to the marketing techniques and clients' engagement in Rural Bank of Paete, Inc. Therefore, the continuous emerging of marketing techniques of the bank can sustain the clients' engagement.

5. That the creation of the marketing design may help and guide the bank for the client's engagement.

Moreover, the study concentrated on the marketing techniques and clients' engagement in Rural Bank of Paete, Inc. and upon assessment of the findings, the study suggests the following recommendations:

1. Overall, the respondents gave importance in acquiring observance in the marketing techniques practices. The Rural Bank of Paete, Inc. may continue to utilize the marketing techniques to master the banking industry.

2. Since the observance level of clients' engagement is also high, there will be no more recommendations but to continue to rely on their marketing techniques and that the employees should always smile because "smile makes the bank healthy".

3. The researcher suggests that there should be a further study by the business management with their marketing techniques to obtain clients' engagement. This recommendation can strengthen the reliability and validity of the results.

4. The more the marketing techniques in Rural Bank of Paete, Inc. evolved and develop and define the company's overall mission and objectives, the more it will create value for customers and build profitable customer relationships which may lead to clients' engagement. Therefore, continue acquiring more emerging techniques in marketing.

5. The output that this study may serve as a guide for Rural Bank of Paete, Inc. They may utilize and adapt the marketing design matrix for sustaining the clients' engagement. However, it can be modified depending on the level of observance of the company.

6. Future researchers should undergo further study of an in-depth analysis based on the level of observance of marketing techniques and clients' engagement of Rural Bank of Paete, Inc. 


\section{References}

Andreti, Junio \& Zhafira, Nabila \& Akmal, Sheila \& Kumar, Suresh (2018) The Analysis of Product, Price, Place, Promotion and Service Quality on Customer's Buying Decision of Convenience Store: A Survey of Young Adult in Bekasi, West Java, Indonesia.

Baldus, B.J., C. Voorhees, and R. Calantone (2015) Online Brand Community Engagement: Scale Development and Validation. Journal of Business Research 68 (5); 978-85.

Berry, Parasuraman and Zeithaml, "Improving Service Quality in America: Lessons Learned," Academy of Management Executive, May 1994, pp. 32-52.

BSP Official Website http://www.bsp.gov.ph

doi: 10.1016/j.busres.2014.09.035.

https://www.businessdictionary.com

https://www.docstoc.com/docs/86421867/LITERATURE-REVIEW-ON-RURAL-BANKING

https://www.forbes.com

https://www.campaigncreators.com/blog/bridge-the-gap-between-sales-and-customer-service-to-improve-customerretention?hs_amp=true

James Rafael Inovero (2015) The Marketing Dynamics and Current Status of Banco Laguna, Inc.

Kabu Khadka \& Soniya Maharjan (2017) Customer Satisfaction and Customer Loyalty

Marketing and the 7Ps: A brief summary of marketing and how it works (www.cim.co.uk/marketingresources) The Chartered Institute of Marketing

Mohammed Moin Uddin Reza (2018) Impact of Brand Loyalty on Improving Customer Retention - A Case Study on Tesco Malaysia (http://ds.doi.org/10.9790/487X-2001064048)

Mojtaba Poorrezaei (2016) Customer Engagement: Conceptualisation, Measurement and Validation

Nashwan Mohammed Abdullah Saif and Wang Aimin (2016) Exploring the Value and Process of Marketing Strategy: Review of Literature (http://dx.doi.org/10.18775/ijmsba.1849-5664-5419.2014.22.1001)

Neil A. Morgan, Kimberly A. Whitler, Hui Feng, and Simos Chari (2018) Research in Marketing Strategy https://www.researchgate.net/publication/327107606_Research_in_Marketing_Strategy

Riikka Säynätjoki (2019) Supporting Customer Retention Through Analytics In Banking Industry

Salome C. Villafranca (2015) The Marketing and Retention Practices of Selected Junkshops in Calamba City

The Principles of Marketing 17th Edition by Philip Kotler and Gary Armstrong (2017)

Vandana Ahuja (Jan 31, 2020) The 7 Functional Benefits of social media for the banking industry (https://customerthink.com/the-7functional-benefits-of-social-media-for-the-banking-industry)

Wahab, N. A., Hassan, L. F. A., Shahid, S. A. M., \& Maon, S. N. (2016). The Relationship between Marketing Mix And Customer Loyalty In Hijab Industry: The Mediating Effect Of Customer Satisfaction. Procedia Economics and Finance, 37, 366371(http://dx.doi.org/10.1016/S2212-5671(16)30138-1)

Xuan Zhang and Yuanyuan Feng (2009) The Impact of Customer Relationship Marketing Tactics on Customer Loyalty 